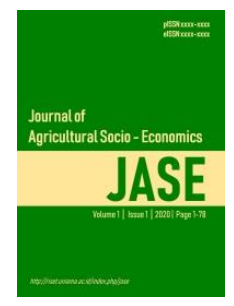

Journal of Agricultural Socio-Economics (JASE)

eISSN 2745-6897 | pISSN 2745-6889

Volum 2 Issue 1 (2021) Page 33-42

DOI:http://dx.doi.org/10.33474/jase.v1i2.6865

Submit: 113-11-2020 | Accepted: 23-03-2021 | Publish: 29-03-2021

\title{
Integration of Indonesian Coffee Markets with World Coffee Markets
}

\author{
Haposan Orlando Napitupulu, Ana Arifatus Sa'diyah*, Farah Mutiara \\ Tribhuwana Tunggadewi University, Malang, Indonesia \\ *E-mail: ana.arifatus@unitri.ac.id
}

\begin{abstract}
This study aims to analyze the integration of the Arabica and Robusta coffee markets in Indonesia with world coffee prices. The study uses secondary data in the form of annual time series data during the period 1985 - 2015. The study uses the VECM analysis method. This method explains the relationship of long-term dynamic equilibrium and short-term equilibrium in a system of equations. The analysis shows that Indonesian and world Arabica coffee is not integrated in the long term or the short term. In Robusta coffee VECM estimation analysis shows that there is a significant value at the $10 \%$ level in a long-term relationship with a value of 0.08579 , which means that there is a short-term relationship between world Robusta coffee prices and domestic Robusta coffee prices in the previous year, but no relationship in the long run.
\end{abstract}

Keywords: coffee, market integration, VAR/VECM

\section{INTRODUCTION}

Coffee (Coffea sp.) Is one of the most important commodities in the world. Coffee is widely cultivated in various countries. Indonesia is the third largest coffee producing country in the world, and as the fourth largest coffee supplier in the world along with Brazil, Colombia and Vietnam (Susilowati, 2007). Coffee is also the third largest agricultural sub-sector commodity after wood and rubber which has an important role as a foreign exchange earner (Sembiring et al., 2008; Meiri et al., 2014).

Indonesian coffee production is mostly to meet foreign market demand. Based on data (Indonesian Coffee Exporters Association, 2016), until 2005, the domestic coffee market only absorbed about 33 percent of the total coffee production, the rest was for export (67\% of Indonesian coffee production). The need for coffee is increasing along with the development of world coffee consumption which shows a positive trend in recent years. Coffee consumption in the world also increased with growth of 2.3 percent per year in 2011 - 2014 (ICO, 2015). The increase in world coffee consumption shows that the market for coffee commodities in the international scope can still develop and become a potential for Indonesia's coffee export market (Kustiari, 2016)( Sudjarmoko, B, 2013).

Until now the target market for Indonesian coffee commodities is still relying on export markets that are spread in various major cities in developed countries including: Japan, the United States, Germany, Italy, and the Netherlands because consumption per capita in the country itself is still very low and growth is also low, while in overseas consumer centers consumption growth seems to be quite steady. Thus, price changes on world and domestic markets have a close relationship and may even influence each other, because the price that will be received by the exporter will be the basis for determining the price to be paid to intermediary traders and ultimately to the producers, or vice versa. Furthermore, the price received by farmers will determine how much volume of coffee production will be sold to the market or to intermediary traders or export traders. If if the price received is satisfactory, the production offered to the market will increase, and vice versa. In an efficient market structure, every change that occurs in one node of the slightest change will propagate to the next node in the commodity supply chain.(Hutabarat, 2016)(Atmadji et al., 2019).

Various tropical coffee-producing countries are currently competing fiercely in world markets to maintain their presence in the hearts of consumers at major market centers through the aggressive assistance and promotion of retailers or roasters at consumer centers. In a market context like this, 
Indonesian coffee has to compete with other coffee-producing countries, although according to various experts, Indonesian coffee has unique characteristics and variety. However, the network, market power and economy of retailers seem to have been able to some extent replace, mix, engineer and create "authentic" coffee flavors in such a way with new product flavors and images, so consumers are not so fanatical about the taste of real coffee, but switch to artificial flavors wrapped in imagery and special attributes (Hardianti, 2016). This is supported by technology and coffee processing machines that are developing rapidly in developed countries. If if the consumer market (end or between) coffee is not integrated with the producer market, then the imbalance between the prices paid by consumers in consumer centers in foreign markets and the prices received by farmers producing coffee in producing countries will widen, so that the development of coffee production in Indonesia will be in vain. For this reason, information and identification of the orientation and response of the Indonesian coffee market to various world consumer markets is important to know in an effort to provide input for policy formulation and steps to improve national coffee.

This study aims to analyze the integration of the Arabica and Robusta coffee markets in Indonesia with world coffee prices and analyze their implications for the formation of coffee prices at the farm level. From this information it is hoped that the right policy can be taken to improve the bargaining position of farmers in the process of determining prices so that farmers.

\section{METHODS}

\subsection{Data source}

The data used in this study are secondary data in the form of annual time series data during the period 1985 - 2015. Data sources were obtained from several related agencies, such as the Directorate General of Plantations, the Central Statistics Agency, International Coffee Organization (ICO) and publications in the form of books and a journal. The data taken includes the price data of Arabica coffee and Robusta coffee domestically and the world.

\subsection{Market Integration Analysis}

Market integration analysis is carried out to see how far the formation of domestic coffee prices is influenced by world level prices. The data used in the form of time series data annual prices of Arabica and Robusta coffee in the year 1985-2015 in the country and world prices. Analysis of market integration in this study refers to the model developed by (Ravallion, 1986)

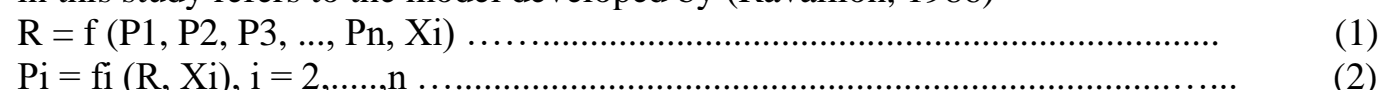

In this case $\mathrm{n}$ the domestic market with the price $\mathrm{P}$; $\mathrm{R}$ is the marketable market price (reference market). $\mathrm{Xi}$ is a seasonal factor and other factors that might affect prices in market $\mathrm{i}$ (including leading markets and markets in other countries). Because equations (1) and (2) only measure prices at the present time, then including the effect of time lag on prices will provide a more dynamic structure. However, if the lag period is too long the model will be complicated, so it is assumed that the price in each market has only one lag phase. More specifically the Ravallion model equation in this study can be written as follows:

$\mathrm{Pt}=$ aiPt-1+bi0Rt+bi1Rt-1+ciXt+et

(3) for $\mathrm{i}=1,2, \ldots$.

n Equation (3) is sensitive to the occurrence of multicollinearity when domestic market prices and references are strongly correlated. Suppose in the form of the first difference (first difference) will reduce the influence of multicollinearity because (Rt-Rt-1) and (Pt-Pt-1) are usually weakly correlated compared to Rt and Pt. This transformation will produce:

Pt-Pt-1 = aiPt-1-Pt-1+bi0Rt+bi1Rt-1+ciXt+ $\mathrm{\varepsilon t}$

(4) If it is assumed that the time series in the local market $(\mathrm{P})$ and in the reference market $(\mathrm{R})$ have the same seasonal pattern, so there is no need to enter dummy variables for seasonality (Xt). Then the equation becomes:

Pt-Pt-1 = aiPt-1-Pt-1+bi0Rt+bi1Rt-1+ et .

(5) Then simplified

to

$\mathrm{Pt}=\mathrm{b} 1 \mathrm{Pt}-1+\mathrm{b} 2(\mathrm{Rt}-\mathrm{Rt}-1)+\mathrm{b} 3 \mathrm{Rt}-1+\varepsilon \mathrm{t}$

In order to obtain unbiased results, time series data regression is performed to detect whether Spuroius Regression occurs, such as:

$\mathrm{P}_{\text {intl }}=\alpha+\beta \mathrm{P}_{\mathrm{d}}+e_{t}$ 
If $\mathrm{P}_{\mathrm{intl}}$ and $\mathrm{P}_{\mathrm{d}}$ has a unit root or Pintl and Pd is not stationary, OLS estimation produces spurious regression. According to Granger and Newbold if $R^{2}>d$ (Durbin Watson), it can be assumed that regression estimation has a spurious problemUji Stasioner Data (Unit Root Test)

Time series price data are generally not stationary. Non-stationary data will produce spurious regression or regression that does not reveal the truth. If this pseudo regression is applied it will result in inaccurate analysis results and result in inappropriate policy making. The stationarity test in this study uses the Augmented Dickey Fuller unit root test (ADF-test). With the test formulation as follows:

$\Delta \mathrm{P}_{\text {intl }}=\alpha+\beta \mathrm{P}_{\mathrm{d}}+e_{\mathrm{t}}$

where intPintl is the first difference from Pintl, assuming that the timeseries data before making the first difference are non-stationary. However, stationarity testing will still be carried out on the initial data before differentiation

The test hypothesis is:

$H 0: \gamma=0$ (the data is not stationary)

$H 1: \gamma<0$ (the data is stationary)

If the absolute value tstatistik> absolute value ttabel in the Dickey-Fuller Table, then the decision taken is to reject $\mathrm{H} 0$ which means the data is stationary. If the absolute value tstatistik <absolute value ttabel then the data is not stationary.

\section{Optimal Lag Test}

Optimal lag length is needed to see the effect of each variable on other variables in the VAR model. The value of the lag of a variable can affect other variables because it takes time for a variable to respond to the movement of other variables. Determination of the optimal lag length can use several criteria, namely: Information Information Criteria (AIC), Schwartz Information Criteria (SIC), HannanQuinn Criteria (HQ), Likelihood Ratio (LR), and Final Prediction Error (FPE). Determination of the optimal lag length in this study uses the optimal lag test results with the criteria for FPE, AIC, SC, smallest HQ, and the largest LR, or can be indicated by the most asterisks (*) in the analysis results.

\section{Cointegration Test}

Cointegration Test in this study uses the Johansen cointegration test. This test is used to see the number of cointegration (rank cointegration) between variables (Rosadi, 2012). The model used to test the cointegration of the price variable is as follows:

Yi $\mathrm{t}=\alpha+\beta \mathrm{Xjt}+\mathrm{Ut}$

Where:

Yt $=$ variable price of Arabica coffee in the domestic market in period t. $(\$ / \mathrm{kg})$

$\mathrm{Xt} \quad=$ variable price of Robusta coffee on the domestic market in period $\mathrm{t} .(\$ / \mathrm{kg})$

$\mathrm{Ut} \quad=$ deviation / deviation (error term)

$\alpha \quad=$ intersep

$\beta \quad=$ parameter coefficient

\section{Granger Causality Test}

Granger Causality Test is performed to see whether two veriabels have a reciprocal relationship or not. In other words, does one variable have a causal relationship with other variables, because every variable in the study have the opportunity to become endogenous or exogenous variables.

\section{Uji Vector Error Correction Model (VECM)}

VECM is used in the model if the time series data is not stationary in level, but stationary in the data is differentiated and cointegrated so that there is a theoretical relationship between variables. VECM is used to measure how price deviations can return to a state of equilibrium. (Hendy. 2000)

Where:

$\mathrm{Yt} \quad=$ the dependent variable is the price of Domestic Arabica coffee in period t. $(\$ / \mathrm{kg})$

$\mathrm{Xt} \quad=$ independent variable in the price of international Arabica coffee in the period t. $(\$ / \mathrm{kg})$

$\Delta \mathrm{Yt}=\mathrm{Yt}-\mathrm{Yt}-1$

$\Delta \mathrm{Xt}=\mathrm{Xt}-\mathrm{Xt}-1$

$\delta \mathrm{ECT}=$ the adjustment mechanism for imbalances that occur in the $\mathrm{t}-\mathrm{n}$ period

(long-term adjustment mechanism) 
VECM analysis explains the relationship between long-term dynamic equilibrium and short-term equilibrium in a system of equations. Although there is a long-term equilibrium between markets, there is a deviation from a short-term equilibrium relationship. It can be said that the cointegration equation is an explanation or benchmark of the long-term equilibrium relationship between markets while the short-term equilibrium relationship may vary significantly. Based on this explanation it can be concluded that VECM is a combination of short-term and long-term relationships between price variables from different markets. (Irawan. 2007)

\section{RESULTS AND DISCUSSION}

\subsection{Stationary Test Data}

The first step that must be done to get the VECM estimate is to test the stationarity of the data of each variable, both the dependent variable and the independent variable. Stationary data is needed to influence the results of the VECM estimation test. In this study, to detect whether or not each stationary variable data is used, the ADF test (Augmented Dickey Fuller) is used. The ADF stationary test of each variable can be shown by the following table:

Table 1. ADF Test Results at Level

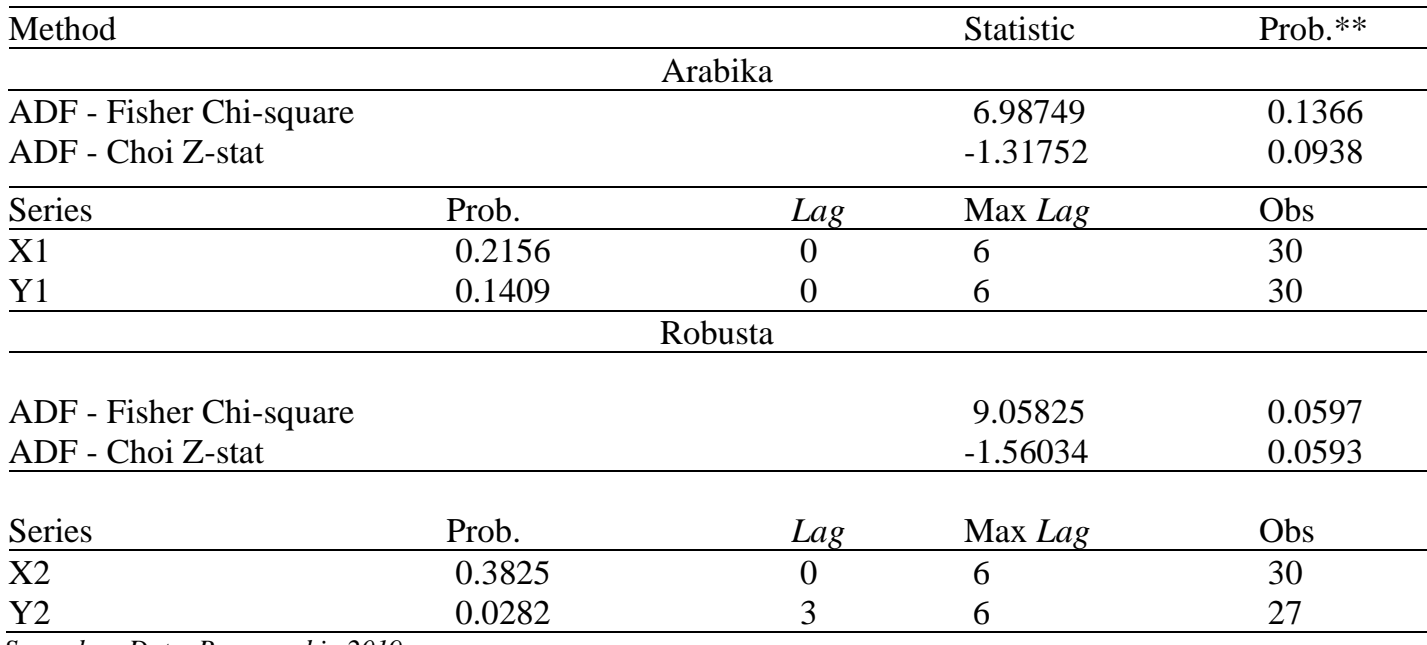

Secondary Data, Processed in 2019

Keterangan: $\quad$ X1 Domestic Arabica Coffee Prices

$Y 1$ World Arabica Coffee Prices

X2 Domestic Robusta Coffee Prices

Y2 World Robusta Coffee Prices

Table 1 shows the variable prices of domestic and world Arabica coffee are not stationary at the level of levels because the probability value greater than $0.05 \%$ is indicated at the $\mathrm{X} 1$ value of 0.1366 and Y1 with a value of 0.0938 . Because the variables X1 and Y1 are not stationary on the ADF level testing. Likewise also with Robusta coffee, Based on the Stationary Test using the ADF Test the results show that the domestic and world Robusta coffee price variables are not stationary at the level because the probability value is greater than $0.05 \%$ (X2 0.0597, and Y2 0593). Because the variables X2 and Y2 are not stationary on the ADF level testing. Furthermore, it requires a data differential at the first difference level. The ADF test results at the physical difference level can be seen in the following table.

Table 2. ADF Test Results at the First Difference Level

\begin{tabular}{|c|c|c|}
\hline Method & Statistic & Prob.** \\
\hline \multicolumn{3}{|c|}{ Arabika } \\
\hline ADF - Fisher Chi-square & 43.1986 & 0.0000 \\
\hline ADF - Choi Z-stat & -5.79331 & 0.0000 \\
\hline Series & Max Lag & Obs \\
\hline
\end{tabular}




\begin{tabular}{|c|c|c|c|c|}
\hline \multicolumn{3}{|l|}{ Method } & \multirow{2}{*}{$\begin{array}{l}\text { Statistic } \\
6\end{array}$} & \multirow{2}{*}{$\begin{array}{l}\text { Prob.** } \\
29\end{array}$} \\
\hline$\overline{\mathrm{D}(\mathrm{X} 1)}$ & 0.0001 & 0 & & \\
\hline $\mathrm{D}(\mathrm{Y} 1)$ & 0.0000 & 0 & 6 & 29 \\
\hline \multicolumn{5}{|c|}{ Robusta } \\
\hline \multicolumn{2}{|c|}{ ADF - Fisher Chi-square } & & 28.9476 & 0.0000 \\
\hline \multicolumn{2}{|c|}{ ADF - Choi Z-stat } & & -4.49785 & 0.0000 \\
\hline Series & Prob. & $L a g$ & Max Lag & Obs \\
\hline $\mathrm{D}(\mathrm{X} 2)$ & 0.0003 & 0 & 6 & 29 \\
\hline $\mathrm{D}(\mathrm{Y} 2)$ & 0.0015 & 1 & 6 & 28 \\
\hline
\end{tabular}

Secondary Data, Processed in 2019

Keterangan: $\quad X 1$ Domestic Arabica Coffee Prices

Y1 World Arabica Coffee Prices

X2 Domestic Robusta Coffee Prices

Y2 World Robusta Coffee Prices

Stationary test results at the first difference level show that the two variables are stationary, this can be seen from the probability value that is smaller than 0.05 by 0.0001 at $\mathrm{X} 1$ and 0.0000 at $\mathrm{Y} 1$ for Arabica coffee and the probability value is smaller than 0.05 with values of 0.0003 at X2 and 0.0015 at Y2 for Robusta coffee. Based on the results of the stationarity test, it can be concluded that all data variables used are stationary in the order I (1) so that it can be said to be free from pseudo regression.

\subsection{Optimal Lag Test Results}

The length of the lag is used to determine the time needed for the effect of each variable on its past variable. In this study, the determination of lag length is done by looking at the smallest FPE, AIC, SC, $\mathrm{HQ}$, and LR criterion values, or can be indicated by the most asterisks $(*)$ in the analysis results. The optimal lag length can be shown in the following table 3 :

Table 3. Optimal Lag Test Results

\begin{tabular}{lclllll}
\hline Lag & LogL & LR & FPE & AIC & SC & HQ \\
\hline 0 & & \multicolumn{5}{c}{ Arabika } \\
1 & -65.25073 & NA & 0.744077 & 5.380058 & 5.477568 & 5.407103 \\
2 & -50.33367 & 1.403415 & 0.432518 & 4.826693 & 5.314244 & 4.961919 \\
3 & -48.31135 & 2.912136 & 0.516790 & 4.984908 & 5.667479 & 5.174224 \\
4 & -42.75347 & 7.114083 & 0.473344 & 4.860278 & 5.737868 & 5.103684 \\
5 & -41.85498 & 1.006315 & 0.645047 & 5.108398 & 6.181009 & 5.405895 \\
6 & -38.70855 & 3.020573 & 0.760552 & 5.176684 & 6.444315 & 5.528271 \\
\hline & & & \multicolumn{2}{c}{ Robusta } & & \\
\hline 0 & -23.92824 & NA & 0.029749 & 2.160686 & 2.258857 & 2.186731 \\
1 & -10.33583 & 23.78671 & $0.013409 *$ & 1.361319 & $1.655833 *$ & $1.439454 *$ \\
2 & -9.113317 & 1.935647 & 0.017067 & 1.592776 & 2.083632 & 1.723001 \\
3 & -6.932214 & 3.089896 & 0.020312 & 1.744351 & 2.431549 & 1.926665 \\
4 & 1.773767 & $10.88248 *$ & 0.014312 & $1.352186 *$ & 2.235726 & 1.586590 \\
5 & 4.762642 & 3.237948 & 0.016708 & 1.436446 & 2.516329 & 1.722940 \\
6 & 7.542623 & 2.548315 & 0.020687 & 1.538115 & 2.814340 & 1.876698 \\
7 & 8.746885 & 0.903197 & 0.031055 & 1.771093 & 3.243660 & 2.161765 \\
\hline
\end{tabular}

* indicates lag order selected by the criterion

LR: sequential modified LR test statistic (each test at $5 \%$ level)

FPE: Final prediction error

AIC: Akaike information criterion

SC: Schwarz information criterion

HQ: Hannan-Quinn information criterion

Data Sekunder, Diolah Tahun 2019 
Based on the explanation Doppy Roy (2019) above can be seen that the lag test results listed in the table above show the Optimal Lag Test used is lag 1, because it has the FPE, AIC, SC, smallest HQ, and the largest LR criteria, or can be indicated by the most asterisks (*) in the results test. Optimal lag test shows in Lag 1 which means that all variables in this study affect each other not only in the current period, but the price variables are interrelated in the previous periodBased on table 5 it can be seen that the match test results listed in the above table show the Optimal Lag Test used is lag 1, because it has the FPE, AIC, SC, smallest HQ, and the largest LR criteria, or can be indicated by the most asterisks (*) on the test results. The use of lag 1 as the optimum lag in the model means that all the variables in the equation affect one another not only in the current period, but the price variables are interrelated in one previous period.

\subsection{Johansen's Cointegration Test Results}

The purpose of the cointegration test in this study is to determine whether groups of variables that are not stationary at these levels meet the requirements of the integration process, ie where all variables have been stationary to the same degree, namely degrees 1, I (1). Johansen's Cointegration Test results are used to determine whether variables that are not stationary have a long-term relationship or not. Long-term information is obtained by first determining the cointegration rank to find out how many systems of equations can explain the whole existing system. Cointegration testing criteria in this study are based on trace statistics. If the trace statistic value is greater than the critical value of 5 percent, then an alternative hypothesis stating the amount of cointegration is accepted so that it can be seen how many equations are cointegrated in the system. This test is to find out whether or not there is a long-term influence for the variables we will examine. If it is proven that there is cointegration, the VECM stage can be continued. But if it is not proven, then VECM cannot be continued. Cointegration test results of domestic Arabica coffee prices with the world can be seen in table 4.

Table 4. Johansen's Cointegration Test Results

\begin{tabular}{|c|c|c|c|c|}
\hline \multicolumn{5}{|c|}{ Arabika } \\
\hline Hypothesized & & Trace & 0.05 & \\
\hline No. of CE(s) & Eigenvalue & Statistic & Critical Value & Prob.** \\
\hline None & 0.208764 & 12.35466 & 15.49471 & 0.1407 \\
\hline At most $1 *$ & 0.174581 & 5.564069 & 3.841466 & 0.0183 \\
\hline Hypothesized & & Max-Eigen & 0.05 & \\
\hline No. of CE(s) & Eigenvalue & Statistic & Critical Value & Prob.** \\
\hline None & 0.208764 & 6.790596 & 14.26460 & 0.5142 \\
\hline At most $1 *$ & 0.174581 & 5.564069 & 3.841466 & 0.0183 \\
\hline \multicolumn{5}{|c|}{ Robusta } \\
\hline None * & 0.458103 & 23.21122 & 15.49471 & 0.0028 \\
\hline At most $1 *$ & 0.171143 & 5.443525 & 3.841466 & 0.0196 \\
\hline Hypothesized & & Max-Eigen & 0.05 & \\
\hline No. of CE(s) & Eigenvalue & Statistic & Critical Value & Prob.** \\
\hline None $*$ & 0.458103 & 17.76769 & 14.26460 & 0.0134 \\
\hline At most $1 *$ & 0.171143 & 5.443525 & 3.841466 & 0.0196 \\
\hline
\end{tabular}

Secondary Data, Processed in 2019

Sign (*)shows significant value at $1 \%$ level

(**)shows a significant value at the level of 5\%

(***)shows a significant value at the level of $10 \%$

Johansen's cointegration test results based on both trace statistics and max-eigenvalue on domestic and world Arabica coffee prices indicate that there is one cointegration at rank $=1(\mathrm{r}=1)$. This can be seen from the Trace Statistic that is greater than the Critical Value of 5\% and the probability value that is less than 5\% (5.564069> 3.841466, and the Prob value 0.0183), as well as the Max-Eigen Statistics. 
Based on these results, there is a long-term relationship or balance in the price of domestic and world Arabica coffee, but in the short term there may not be a balance.

Johansen's cointegration test results based on both trace statistics and max-eigenvalue on domestic and world Arabica coffee prices indicate that there are two cointegration at rank $=1(\mathrm{r}=1)$, and at rank $=0$ (none). This can be seen from the Trace Statistics that are greater than the Critical Value of 5\% and the probability value is less than 5\% with a value of 23.21122> 15.49471, and the Prob value. 0.0028 at rank $=0$ (none) and a value of 5.443525> 3.841466, and a Prob value. 0.0196 at rank $=1(\mathrm{r}=1)$, as well as Max-Eigen Statistics with a value of 17.76769> 14.26460, and Prob. 0.0134 at rank $=0$ (none) and a value of 5.443525> 3.841466, and a Prob value. 0.0196 at rank $=1(\mathrm{r}=1)$. Based on these results, there is a long-term relationship or balance in the price of domestic and world Arabica coffee

\subsection{Granger Causality Test}

Granger causality test is performed to see the relationship between two variables whether they have a reciprocal relationship or not. This test can be used to see whether price developments in a market can cause changes or price movements in other markets by seeing these prices as exogenous and endogenous variables and vice versa.

Table 5. Granger Causality Test Results

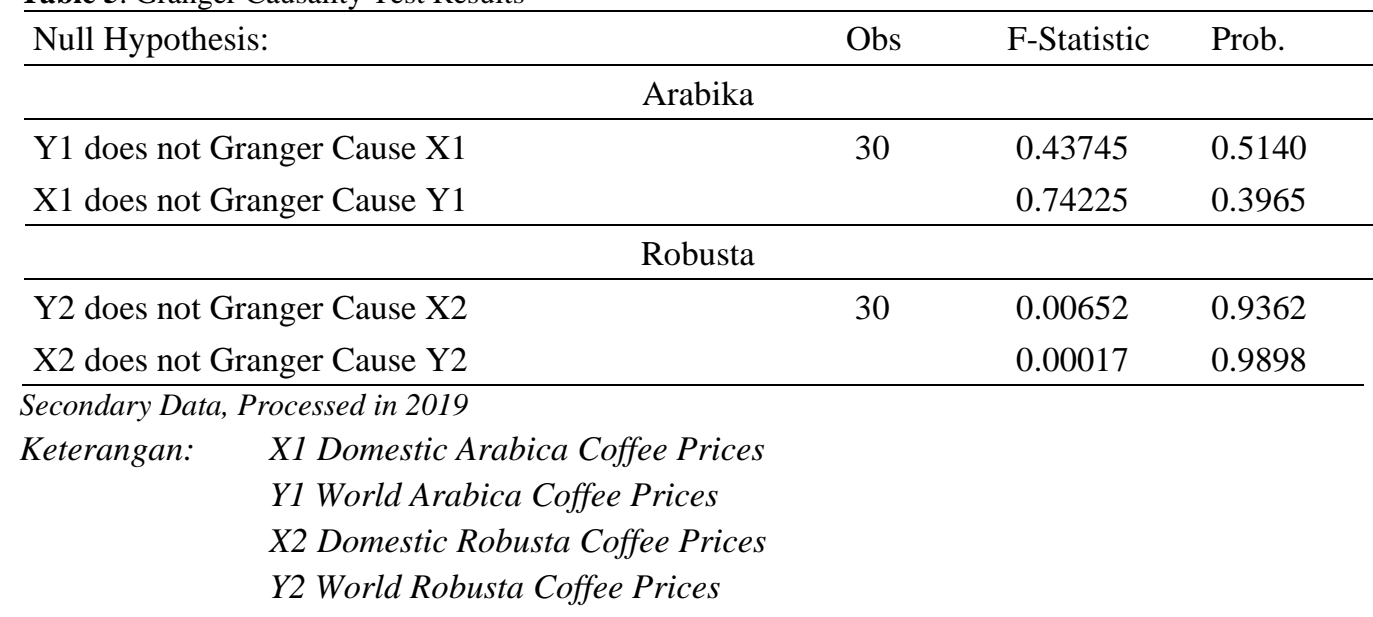

Table 5 shows the probability value of domestic Arabica coffee prices to the world and vice versa greater than 0.05 (insignificant) $\mathrm{Y} 1$ to X1 of 0.5140 and X1 to $\mathrm{Y} 1$ of 0.3965 . Independent or in other words there is no influence between each other Likewise with robusta coffee 0.05 (insignificant) $\mathrm{Y} 2$ to $\mathrm{X} 2$ of 0.9362 and $\mathrm{X} 2$ to $\mathrm{Y} 2$ of 0.9898 . Independent or in other words there is no influence between each other.

\subsection{Test Vector Error Correction Model}

In determining the lag the results obtained show lag 1 which has a value in accordance with the criteria. Then, for VECM modeling, it will use lag 1. Numbers in the table - which do not have brackets are parameter values then the numbers in () in the table are standard errors and the numbers in [] in the table are values from tcount. The results of the VECM model parameter estimation can be explained in the following table.

Table 6. Test Vector Error Correction Model (Long Term)

\begin{tabular}{|c|c|c|c|}
\hline Cointegrating Eq: & CointEq1 & Cointegrating Eq: & CointEq1 \\
\hline \multicolumn{2}{|c|}{ Arabika } & \multicolumn{2}{|c|}{ Robusta } \\
\hline $\bar{X} 1(-1)$ & 1.000000 & $\mathrm{X} 2(-1)$ & 1.000000 \\
\hline \multirow[t]{3}{*}{$\mathrm{Y} 1(-1)$} & 0.126524 & $\mathrm{Y} 2(-1)$ & -1.347627 \\
\hline & $(0.33617)$ & & $(0.27711)$ \\
\hline & {$[0.37636]$} & & {$[-4.86320]$} \\
\hline
\end{tabular}

Secondary Data, Processed in 2019

$[-4.86320]$

Keterangan: 
X1 Domestic Arabica Coffee Prices

$Y 1$ World Arabica Coffee Prices

X2 Domestic Robusta Coffee Prices

Y2 World Robusta Coffee Prices

- number in ( ) is the standard error and

- number in [ ] is the value of t-count

VECM test results in table 6 show that the error correction (Error Correction Term) on domestic and world Arabica coffee prices is not significant at the real level either $1 \%, 5 \%$, or $10 \%$ with a value of 0.33617 or in other words it is still in the standard error by $30 \%$. This insignificant ECT value indicates that there is no significant relationship between domestic Arabica coffee prices and world Arabica coffee prices. The table above is the VECM test results that show a long-term relationship. Based on table 6 it can also be seen that there is no significant value on the test results either in the X1 (-1) variable or in the Y1 (-1) variable, or in other words not there is a long-term relationship between the price of domestic Arabica coffee with the world.In Robusta coffee, the VECM test results listed in table 13 show that the Error Correction Term on domestic and world Arabica coffee prices is not significant at either $1 \%, 5 \%$, or $10 \%$ levels with a value of 0.27711 . This insignificant ECT value indicates that there is no significant relationship between domestic Arabica coffee prices and world Arabica coffee prices. The table above shows the VECM test results that show a long-term relationship. Based on table 6 it can also be seen that there is no significant value in the test results either in the $\mathrm{X} 2$ (-1) variable or in the Y2 (-1) variable, or in other words it is not there is a long-term relationship between domestic and world Robusta coffee prices.

Table 7. Test Vector Error Correction Model (Short Term)

\begin{tabular}{lcccc}
\hline Error Correction: & $\mathrm{D}(\mathrm{X} 1)$ & $\mathrm{D}(\mathrm{Y} 1)$ & $\mathrm{D}(\mathrm{X} 1)$ & $\mathrm{D}(\mathrm{Y} 1)$ \\
\hline CointEq1 & \multicolumn{3}{c}{ Arabika } & \multicolumn{2}{c}{ Robusta } \\
& -0.319396 & -0.051128 & -0.028647 & 0.306053 \\
& $(0.13223)$ & $(0.20881)$ & $(0.08579)$ & $(0.10436)$ \\
& {$[-2.41554]$} & {$[-0.24486]$} & {$[-0.33391]$} & {$[2.93272]$} \\
$\mathrm{D}(\mathrm{X} 1(-1))$ & 0.002284 & 0.332030 & -0.189362 & -0.001483 \\
& $(0.19521)$ & $(0.30826)$ & $(0.22245)$ & $(0.27059)$ \\
& {$[0.01170]$} & {$[1.07711]$} & {$[-0.85126]$} & {$[-0.00548]$} \\
& & & & \\
$\mathrm{D}(\mathrm{Y} 1(-1))$ & 0.129788 & -0.275292 & 0.294161 & 0.208683 \\
& $(0.12885)$ & $(0.20347)$ & $(0.16678)$ & $(0.20288)$ \\
& {$[1.00728]$} & {$[-1.35296]$} & {$[1.76375]$} & {$[1.02862]$} \\
& & & & \\
$\mathrm{C}$ & 0.016363 & -0.020063 & 0.061957 & -0.042002 \\
& $(0.11087)$ & $(0.17508)$ & $(0.06937)$ & $(0.08438)$ \\
& {$[0.14759]$} & {$[-0.11459]$} & {$[0.89315]$} & {$[-0.49776]$} \\
R-squared & 0.204840 & & & \\
\hline
\end{tabular}

Secondary Data, Processed in 2019

Keterangan:

X1 Domestic Arabica Coffee Prices

$Y 1$ World Arabica Coffee Prices

X2 Domestic Robusta Coffee Prices

Y2 World Robusta Coffee Prices

- number in ( ) is the standard error and

- number in [ ] is the value of t-count

Based on table 7 it can also be seen that there is no significant value in lag 1, in the price of domestic Arabica coffee or the price of world Arabica coffee (0.19521 X1 against the price itself, 
$0.30826 \mathrm{X} 1$ against $\mathrm{Y} 1$, and $0.12885 \mathrm{Y} 1$ against the price itself and 0.20347 against $\mathrm{X} 1$ ) which indicates the absence of short-term relationships that affect each other prices or the price itselfVECM test results in table 7 if seen each of the variables in the short term in the table can be seen in CointegrationEq, there is a significant value at the level of $10 \%$ with a value of 0.08579 , which means that there is a short-term relationship between world Robusta coffee prices and prices domestic Robusta coffee one year before. This shows that an increase of US \$ 1 in the world Robusta coffee price in the previous year will cause a decrease in the current Robusta coffee price of US \$ 0.306The results of the analysis after testing at each stage shows conclusions that are inversely proportional to hypotheses or provisional estimates, on the other hand support some data and literature statementsGranger causality test shows that there is no relationship of influence or influence between variables, in other words it is independent. This supports data that the world coffee market does not depend on export volumes from Indonesia, based on the ITC (International Trade Center, 2015) which is also supported by research from I Made Pradityarjuna (Integration of the Indonesian and US Coffee Markets and the Effects of Exchange Rate Shocks on Prices Indonesian Coffee, 2016) Indonesia is only ranked 5th as a coffee importing country to the United States or as the largest coffee importing country in the world, indirectly reducing the volume of Indonesian exports has little effect or even does not reduce the consumption or volume of American coffee imports, and and vice versa, both Arabica and Robusta coffee.Overall from the results of the VECM analysis on the price of Arabica coffee and Robusta coffee on the domestic and world markets there is no long-term relationship. VECM analysis also shows that there is no short-term relationship between domestic and world Arabica coffee, compared with Robusta coffee prices, domestic and world Robusta coffee prices have a short-term relationship. This indicates in the short term between the price of domestic Robusta coffee and integrated world Robusta coffee. This explanation is supported by data that according to ICO (2015) the amount of world coffee consumption is dominated by Arabica coffee with almost $70 \%$, while world Robusta coffee consumption is only $28 \%$, inversely proportional to the amount of Indonesian coffee exports to the world market which is almost $70 \%$ is held by Robusta coffee and $30 \%$ is Arabica (AEKI, 2016).

The results of the analysis show the suitability that Robusta coffee between Indonesia and the world is integrated because the results of the VECM analysis show a short-term relationship. The shortterm relationship of Indonesian Robusta coffee prices with international ones is still not enough, given that the Indonesian coffee market is still very dependent on the international market. This is still very far from the government's expectation of the contribution of coffee commodity as one of the country's foreign exchange earning commodities, the relationship between the price of both Arabica and Robusta coffee in the Domestic and International markets is still classified as market failure because it is still not integrated in the long and short term in Arabica coffee and in the long run for Robusta coffee. Market Failure itself indicates that there is asymmetric information in the relationship between the two markets, or the transmission of prices is not channeled properly (Anindita 2017).

\section{CONCLUSION}

Based on the analysis of the integration of Indonesian Arabica coffee prices with the world and the integration of Indonesian Robusta coffee prices with the world with the vector error correction model (VECM), the following conclusions can be drawn:

\subsection{Integration of Indonesian Arabica Coffee Prices}

In the johansen cointegration test on Indonesian and world Arabica coffee the results of the analysis showed a significant value, or in another sense the price of Indonesian Arabica and world cointegration occurred, and Analysis continues to VECM, the Indonesian Arabica coffee and the world estimates show that there is no significant value, indicating that there is no important relationship between the price of Indonesian Arabica coffee and the world both in the long term or short term.

\subsection{Integration of Robusta Coffee Prices}

In the johansen cointegration test of Indonesian and world Robusta coffee, the results of the analysis indicate a significant value, or in another sense the price of Robusta coffee in Indonesia and the world of cointegration occurs, and In Robusta coffee VECM estimation analysis shows that there is a significant value at the level of $10 \%$ in a long-term relationship with a value of 0.08579 , which means that there is a short-term relationship between world Robusta coffee prices and domestic Robusta coffee prices in the previous year, but there is no long-term relationship. 


\section{REFERENCE}

Anindita, R., \& Baladina, N. (2017). Pemasaran produk pertanian. Penerbit. Andi. Yogyakarta.

Asosiasi Eksportir Kopi Indonesia. 2016. Konsumsi Kopi Domestik (ID): AEKI. http://www.aekiaice.org/industri_kopi_aeki.html

Atmadji, E., Priyadi, U., \& Achiria, S. (2019). Perdagangan Kopi Vietnam Dan Indonesia Di Empat Negara Tujuan Ekspor Kopi Utama: Penerapan Model Constant Market Share. Jurnal Ilmu Ekonomi Dan Pembangunan, 19(1), 38-48.

Hardianti, I. D. (2016). Upaya Brazil Untuk Mempertahankan Posisi Produsen Terbesar Dalam Pasar Kopi Global. Jurnal Universitas Airlangga, 186-196. https://www.google.com/url?sa=t\&rct=j\&q=\&esrc=s\&source=web\&cd=2\&cad=rja\&uact $=8 \& \mathrm{v}$ ed=2ahUKEwjztJq94ZrgAhWLLY8KHSvrC3UQFjABegQICRAC\&url=http\%3A\%2F\%2Fjour nal.unair.ac.id\%2Fdownload-fullpapersjahi20ae416a00full.pdf\&usg=AOvVaw0SSEj9oiAuTEL-W8SQhPj8

Hutabarat, B. (2016). Analisis Saling-Pengaruh Harga Kopi Indonesia dan Dunia. Jurnal Agro Ekonomi, 24(1), 21. https://doi.org/10.21082/jae.v24n1.2006.21-40

Kustiari, R. (2016). Perkembangan Pasar Kopi Dunia dan Implikasinya bagi Indonesia. Forum Penelitian Agro Ekonomi, 25(1), 43. https://doi.org/10.21082/fae.v25n1.2007.43-55

Meiri, A., Nurmalina, R., \& Rifin, A. (2014). Analisis Perdagangan Kakao Indonesia di Pasar Internasional. 1(1), 29-40. https://doi.org/10.21082/jtidp.v4n1.2013.p39-46

Ravallion, M. (1986). Testing Market Integration. American Journal of Agricultural Economics, 68(1), 102-109. https://doi.org/10.2307/1241654

Sembiring, S. A., Harianto, Siregar, H., \& Saragih, B. (2008). Dampak Kebijakan Pemerintah Melalui Instruksi Presiden Tahun 2005-2008. Forum Pascasarjana, 35(1), 15-24.

Susilowati, S. H. (2007). Dampak Kebijakan Ekonomi di Sektor Agroindustri terhadap Distribusi Pendapatan dan Kemiskinan di Indonesia. Thesis. 